\title{
Effect of extended visiting hours on physician distractions in the ICU: a before-and-after study
}

\author{
Kay Choong See ${ }^{1 *}$, Xie Ying Song ${ }^{2}$ and Han Tun Aung ${ }^{2}$
}

\section{Main text}

Extending visiting hours in adult intensive care units (ICUs) promotes family-centered care, but physicians may be concerned about increased distractions from visitors [1]. We sought empirical evidence within our 20-bed medical ICU, assuming that distractions could cause medical errors [2].

During office hours (07.30 to 17.30 on weekdays; 07.30-12.30 on weekends), two physician teams shared the patient load. Each team comprised one attending physician, one senior resident, and two junior residents. Observations of residents, being front-line medical staff, were performed during two time periods, before and after implementation of extended visiting hours in 2015. For each time period, observations were performed by different groups of six nurse researchers, following a standard method [3]. For each observation session lasting 150$180 \mathrm{~min}$, a pair of observers (A and B) independently recorded the duration, type, source, and severity of distractions. Distractions were defined as breaks in attention, evidenced by observed behaviour such as orienting away from a task or responding verbally [4]. Analysis was based on the data of observer A only, while reliability was assessed using the data from observer B. All physicians gave informed consent to be observed, and no one declined participation. Ethics approval was obtained (DSRB/ 2011/00279).
From 11 May to 26 June 2011 (previously reported [3]), visiting hours were restricted to $12.00-14.00$ and 17.00 to 20.00 (total $5 \mathrm{~h}$ ), and from 8 May to 9 July 2017, visiting hours were extended to 09.0021.00 (total $12 \mathrm{~h}$ ). Mean distraction frequency did not differ between both time periods $(4.36 \pm 2.27 / \mathrm{h}$ versus $5.00 \pm 2.68 / \mathrm{h}, t$ test $P=0.262$ ), even after adjusting for resident seniority using multiple linear regression $(P=0.303)$. The distribution of current activities and distraction characteristics differed, though predominant type, sources, and severity of distractions were similar (Table 1). The duration of distractions was short, and median duration per distraction was shorter in the later time period (2 min versus $1 \mathrm{~min}, P<0.005)$. Reliability, as assessed by agreement of all observed distractions between observers $\mathrm{A}$ and $\mathrm{B}$, was excellent in both time periods (99.1\% and $96.1 \%$, respectively).

Overall, distractions among ICU doctors were common ( 4-5 distractions/doctor/h), and this is consistent with data from other studies using different observation methods [5]. There was also no significant increase in the frequency of distractions after implementation of extended visiting hours in the ICU. Being asked to speak to family members constituted a small proportion $(<5 \%)$ of the distractions, and therefore our study did not provide empirical support for the concern of increased distractions from visitors due to extended visiting hours.

Full list of author information is available at the end of the article 
Table 1 Characteristics of distractions

\begin{tabular}{|c|c|c|c|}
\hline Variables studied & Restricted visiting hours & Extended visiting hours & $P$ value \\
\hline Sessions observed & 38 & 39 & NA \\
\hline Total observation time, $\mathrm{h}$ & 100.4 & 117 & NA \\
\hline Number of distractions & 444 & 585 & NA \\
\hline \multicolumn{4}{|l|}{ Start time of sessions observed } \\
\hline Morning (07.30-12.00), n (\%) & $23(60.5)$ & $21(53.8)$ & 0.554 \\
\hline Afternoon (12.00-17.30), $n(\%)$ & $15(39.5)$ & $18(46.2)$ & \\
\hline Frequency of distractions $/ \mathrm{h}$, mean $\pm \mathrm{SD}$ & $4.36 \pm 2.27$ & $5.00 \pm 2.68$ & 0.262 \\
\hline Distraction duration (min), median (IQR) & $2(2-4)$ & $1(1-2)$ & $<0.001$ \\
\hline Current activity at the time of distraction, $n(\%)$ & & & $<0.001$ \\
\hline Writing notes & $97(21.8)$ & $150(25.6)$ & \\
\hline Conducting ward round & $84(18.9)$ & $35(6.0)$ & \\
\hline Entering treatment orders & $75(16.9)$ & $148(25.3)$ & \\
\hline Reading notes & $61(13.7)$ & $162(27.7)$ & \\
\hline Talking to a colleague & $47(10.6)$ & $49(8.4)$ & \\
\hline Examining a patient & $37(8.3)$ & $11(1.9)$ & \\
\hline Entering medication orders & $14(3.2)$ & $3(0.5)$ & \\
\hline Performing non-sterile procedure & $11(2.5)$ & $7(1.2)$ & \\
\hline Performing sterile procedure & $9(2.0)$ & $9(1.5)$ & \\
\hline Talking to a patient & $3(0.7)$ & $4(0.7)$ & \\
\hline Talking to a patient's relative & $3(0.7)$ & $6(1.0)$ & \\
\hline Performing resuscitation & $2(0.5)$ & $0(0.0)$ & \\
\hline Giving medications & $1(0.2)$ & $1(0.2)$ & \\
\hline Type of distraction, $n(\%)$ & & & $<0.001$ \\
\hline Asked to speak to colleague & $177(39.9)$ & $367(62.7)$ & \\
\hline Asked to write treatment orders & $61(13.7)$ & $43(7.4)$ & \\
\hline Asked to attend to a patient & $61(13.7)$ & $25(4.3)$ & \\
\hline Asked to sign a document & $31(7.0)$ & $5(0.9)$ & \\
\hline Going to the toilet/going elsewhere & $30(6.8)$ & $89(15.2)$ & \\
\hline Asked to perform a procedure & $29(6.5)$ & $7(1.2)$ & \\
\hline Asked to speak to a patient's relative & $25(5.6)$ & $18(3.1)$ & \\
\hline Drinking/eating & $21(4.7)$ & $14(2.4)$ & \\
\hline Asked to write medication orders & $7(1.6)$ & $13(2.2)$ & \\
\hline Asked to administer medications & $2(0.5)$ & $4(0.7)$ & \\
\hline Source of distraction, $n(\%)$ & & & 0.026 \\
\hline Other doctor & $156(35.1)$ & $207(35.4)$ & \\
\hline Nurse & $135(30.4)$ & $147(25.1)$ & \\
\hline Self & $83(18.7)$ & $164(28.0)$ & \\
\hline Phone call & $30(6.8)$ & $28(4.8)$ & \\
\hline Other healthcare worker & $24(5.4)$ & $21(3.6)$ & \\
\hline Relative & $14(3.2)$ & $15(2.6)$ & \\
\hline Patient & $1(0.2)$ & $2(0.3)$ & \\
\hline Monitor alarm & $1(0.2)$ & $1(0.2)$ & \\
\hline Severity of distraction, $n(\%)$ & & & $<0.001$ \\
\hline No effect on activity & $13(2.9)$ & $82(14.0)$ & \\
\hline Momentary pause $\mathrm{a}^{\mathrm{a}}$ & $136(30.6)$ & $193(33.0)$ & \\
\hline Complete pause $^{\mathrm{b}}$ & $210(47.3)$ & $288(49.2)$ & \\
\hline Abandons activity, attends to distraction & $85(19.1)$ & $22(3.8)$ & \\
\hline
\end{tabular}

${ }^{a}$ Activity resumes during distraction

${ }^{\mathrm{b}}$ Activity resumes only after distraction ceases

$I Q R$ interquartile range, $N A$ not applicable, $S D$ standard deviation 


\section{Abbreviation}

ICU: Intensive care unit

\section{Acknowledgements}

The authors would like to thank the research nurses from Ngee Ann Polytechnic, Singapore, for assisting with the data collection.

\section{Funding}

None.

\section{Availability of data and materials}

The dataset used and analysed during the current study are available from the corresponding author on reasonable request.

\section{Authors' contributions}

KCS, XYS, and HTA conceived the study, participated in the design, and collected the data. KCS performed the statistical analysis and drafted the manuscript. All authors read and approved the final manuscript.

\section{Ethics approval and consent to participate}

Ethics approval was obtained from the National Healthcare Group Domain Specific Review Board (ethics approval number DSRB/2011/00279). All participating physicians gave informed consent to be observed.

\section{Consent for publication}

Not applicable.

\section{Competing interests}

The authors declare that they have no competing interests.

\section{Publisher's Note}

Springer Nature remains neutral with regard to jurisdictional claims in published maps and institutional affiliations.

\section{Author details}

${ }^{1}$ Division of Respiratory and Critical Care Medicine, University Medicine Cluster, National University Hospital, 1E Kent Ridge Road, NUHS Tower Block Level 10, 119228 Singapore, Singapore. ${ }^{2}$ School of Health Sciences, Ngee Ann Polytechnic, 535 Clementi Rd., 599489 Singapore, Singapore.

Received: 16 August 2017 Accepted: 29 August 2017

\section{Published online: 18 September 2017}

\section{References}

1. Soury-Lavergne A, Hauchard I, Dray S, Baillot ML, Bertholet E, Clabault K, Jeune S, Ledroit C, Lelias I, Lombardo V, et al. Survey of caregiver opinions on the practicalities of family-centred care in intensive care units. J Clin Nurs. 2012;21(7-8):1060-7.

2. Westbrook Jl, Woods A, Rob Ml, Dunsmuir WT, Day RO. Association of interruptions with an increased risk and severity of medication administration errors. Arch Intern Med. 2010;170(8):683-90.

3. See KC, Phua J, Mukhopadhyay A, Lim TK. Characteristics of distractions in the intensive care unit: how serious are they and who are at risk? Singapore Med J. 2014;55(7):358-62.

4. Anthony K, Wiencek C, Bauer C, Daly B, Anthony MK. No interruptions please: impact of a No Interruption Zone on medication safety in intensive care units. Crit Care Nurse. 2010;30(3):21-9.

5. Ballermann MA, Shaw NT, Mayes DC, Gibney RN, Westbrook JI. Validation of the Work Observation Method By Activity Timing (WOMBAT) method of conducting time-motion observations in critical care settings: an observational study. BMC Med Inform Decis Mak. 2011;11:32.

\section{Submit your next manuscript to BioMed Central and we will help you at every step: \\ - We accept pre-submission inquiries \\ - Our selector tool helps you to find the most relevant journal \\ - We provide round the clock customer support \\ - Convenient online submission \\ - Thorough peer review \\ - Inclusion in PubMed and all major indexing services \\ - Maximum visibility for your research \\ Submit your manuscript at www.biomedcentral.com/submit

